\title{
An Application of Herbal Cough Medicine Selection Using Electre Method
}

\author{
Mila Jumarlis ${ }^{1}$, Raden Wirawan ${ }^{2}$, Suardi $\mathrm{M}^{3}$ \\ \{milajumarlis@stainmajene.ac.id ${ }^{1}$, radenwirawan@almitra.ac.id ${ }^{2}$, suardi@handayani.ac.id ${ }^{3}$ \} \\ ${ }^{1}$ Department of Communication and Islamic Broadcasting, Sekolah Tinggi Agama Islam Negeri Majene, Indonesia. 91415 \\ ${ }^{2}$ Department of Computer Engineering, Sekolah Tinggi Manajemen Informatika dan Komputer Bina Adinata, Bulukumba, \\ Indonesia. 92513 \\ ${ }^{3}$ Department of Information System, Sekolah Tinggi Manajemen Informatika dan Komputer Handayani Makassar, \\ Indonesia. 90231
}

\begin{abstract}
Nowdays, the development of traditional health services uses increasingly rapid concoctions. The use of herbal medicine as an alternative medicine by the Indonesian is not a new thing. Indonesia is a country that has a variety of plants that can be used as herbal medicines, including the use of herbal medicines for coughing. This study aims to design an application for selecting herbal cough medicines to make it easier for people to choose and recognize medicinal plants suitable for coughing. The algorithm used is Elimination and Choice Expressing Reality (ELECTRE) with the outranking concept using pairwise comparisons of alternatives based on each appropriate criterion. The research design used in building this system is structured UML and Software used by PHP and MySql for database processing. The results of this study are an application that is able to recommend herbs that are appropriate for each web-based cough category where electre will determine the ranking of the best alternatives of several types of herbal medicines according to the category or type of cough.
\end{abstract}

Keywords : Application, Cough, Electre, Herbal Medicine, Web

\section{Introduction}

The development of traditional health services using herbs is increasingly rapid, as evidenced by the results of the 2010 Basic Health Research that the percentage of Indonesian population who had consumed herbal medicine was $59.12 \%$ found in all age groups, both men and women, in rural and urban areas. Indonesian society has since time immemorial used herbal or traditional medicine as an effort to maintain health, prevent disease and health care [1][2]. As the Prophet said, "God does not bring down disease except He also decreases the antidote". The use of Herbal Medicine as an alternative medicine by the Indonesian people is not new. Included in the use of herbal medicines for coughing. Coughing has several categories, namely coughing up phlegm and dry cough, coughing cold and whooping cough [3][4]. From several categories of cough above, herbal medicine recommendations are needed that are suitable for the type of cough that is experienced So it is deemed necessary to design a system that helps people to choose and recognize the right herbal cough medicine.

Some of the previous researchers who discussed cough medicine and herbal plants were Haryo.VB (Decision Support System for Deciding Medicinal Plants According to the Type of Disease Using the TOPSIS Method)[5], Ismail.P (Implementation of Analytical Hierarchy Process - TOPSIS and Borda Selection of Medicinal Plants for Cough Disease)[6] and Utami.M (Decision Support System for Choosing Cough Drugs using the Product Weight Method[7]). Based on this study, the authors conducted a research application for herbal cough drug selection using the electre method to facilitate the search for good medicinal plants from several alternative herbal medicinal herbs proposed and can display the value of the results of ranking herbal medicines to be chosen by the community. Because every disease has a cure. 


\section{Material and Methods}

The research method used in making this system consists of data collection processes and system design analysis processes. In collecting data obtained through observation, interviews, and literature. The research design used in this study is UML which is structured designed which consists of the design of use case diagram models, activity diagrams, sequence diagrams, and class diagrams. The software used in building this system is PHP and MySql for database processing while the algorithm used is Elimination And Choice Expressing Reality (Electre) with the concept of outranking using paired comparisons of alternatives based on each appropriate criteria [8][9].

The electre method is included in the multicriteria decision-making analysis method originating in Europe in the 1960s. ELECTRE is an acronym for Elimination Et Choix Traduisant la Realité or in English means Elimination and Choice Expressing Reality. Electre is one of the multicriteria decisions making methods based on outranking concepts using pairwise comparisons of alternatives based on each appropriate criterion. The Electre method is used in conditions where alternatives that are not in accordance with the criteria are eliminated and suitable alternatives can be produced [8][10][11]. Following are the compatibility rating between criteria and assessment indicators used in selecting cough herbal medicines.

Table 1. Table of criteria for herbal cough medicines

\begin{tabular}{|c|c|c|}
\hline CRITERIA & INFORMATION & VALUE \\
\hline \multirow{4}{*}{ Economy Level (K1) } & Expensive Rp. $20.000-25.000 / 100 \mathrm{gr}$ & 1 \\
\hline & Quite Expensive Rp. 15.000 - 20.000/100gr & 2 \\
\hline & Cheap Rp. $10.000-15.000 / 100 \mathrm{gr}$ & 3 \\
\hline & Very Cheap Rp. $5.000-10.000 / 100 \mathrm{gr}$ & 4 \\
\hline \multirow{4}{*}{ Flavor (K2) } & Bitter & 1 \\
\hline & Spicy & 2 \\
\hline & Acid & 3 \\
\hline & Sweet & 4 \\
\hline \multirow{4}{*}{ Aroma (K3) } & Very Stinging & 1 \\
\hline & Quite Stinging & 2 \\
\hline & Sting & 3 \\
\hline & Not Stinging & 4 \\
\hline \multirow{4}{*}{ Effect (K4) } & Ineffective & 1 \\
\hline & Less effective & 2 \\
\hline & Effective enough & 3 \\
\hline & Very effective & 4 \\
\hline \multirow{4}{*}{ Availability (K5) } & Outside the island & 1 \\
\hline & Outside the Makassar area & 2 \\
\hline & Family medicinal plants & 3 \\
\hline & Makassar area & 4 \\
\hline
\end{tabular}

The step in the electre algorithm is the first stage of normalization, the next two stages of weighting are the third stage the criteria are divided into two subsets, namely concordance and discordance. Then the fourth step is done, namely to determine the value of the concordance matrix elements is to add the weights included in the concordance set. To determine the value of the elements in the discordance matrix by dividing the maximum difference in criteria included in the set of discordance sections with the maximum difference in the value of the existing criteria. In the fifth stage an F matrix is formed as a dominant concordance and discordance matrix that can be constructed by comparing each value of the matrix concordance element and discordance with the threshold value. After 
the $\mathrm{F}$ matrix is formed, then a $\mathrm{G}$ matrix is formed as the dominant discordance matrix can be built with the help of a threshold value. At this stage an E matrix is formed as an aggregate dominance matrix, where each element is a multiplication of elements of matrix $F$ with corresponding $\mathrm{G}$ matrix elements. The $\mathrm{E}$ matrix gives a sequence of choices for each alternative, that is : if ekl $=1$ then alternative Ak is a better alternative than A1. So, the lines in matrix $\mathrm{E}$ that have the least amount of ekl $=1$ can be eliminated. Thus, the best alternative is an alternative that dominates other alternatives.

\section{Results and Discussion}

\subsection{System Planning}

The process of selecting herbal medicines for coughing requires a system that can help the user in determining herbal remedies for coughing. The system needed is an onlinebased system and provides information about several alternative herbal remedies for cough accompanied by the criteria for each alternative herbal medicine. Next is the system design using the Unified Modeling Language program to describe the proposed system processes with use case diagrams and class diagrams.

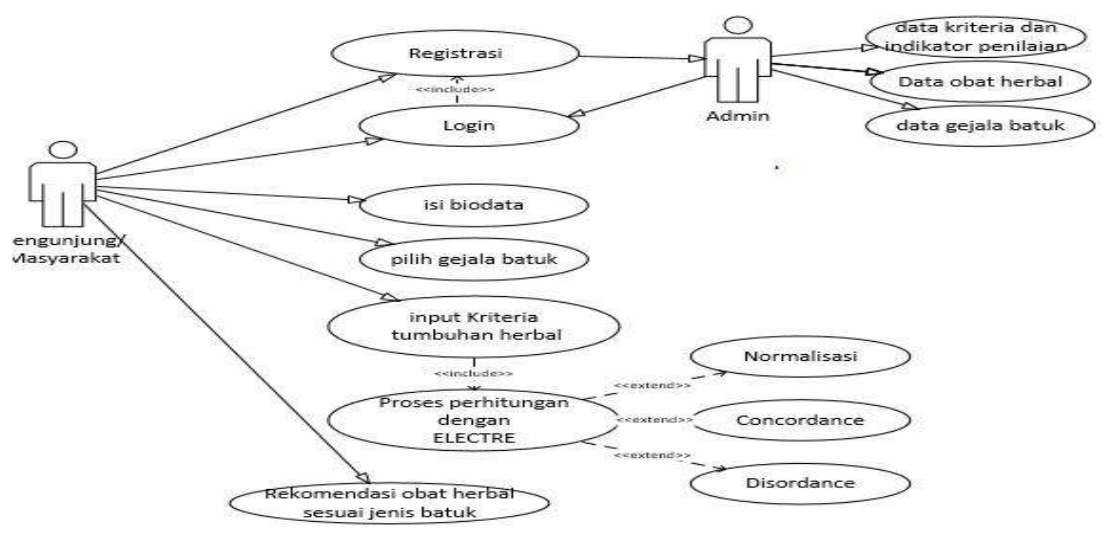

Figure 1. Use Case Diagram

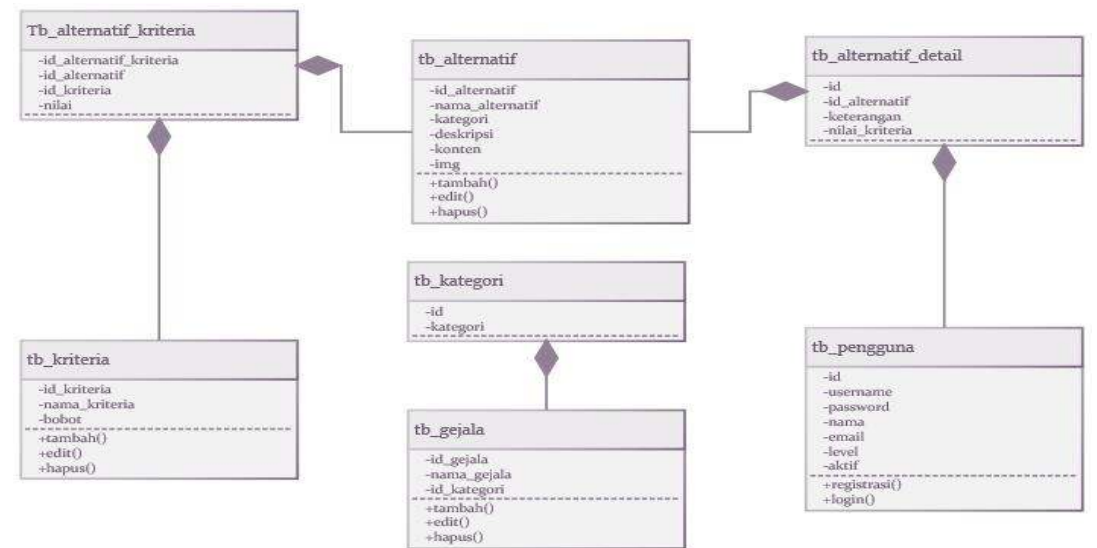


Figure 2. Class Diagram

In figure 1 use case diagram explains that there are two actors, namely admin who has login function, managing user data, alternative crop criteria data, and symptom data. While users can access the website, register, $\log$ in, choose symptoms, input crop criteria and see plant recommendations that are suitable for the type of cough. Figure 2 Class diagrams describe the static structure of classes in the system. Class diagrams represent something that is handled by the system, namely recommendations for cough herbal medicines handled by the system.

\subsection{System Design}

\section{a. Input Design}

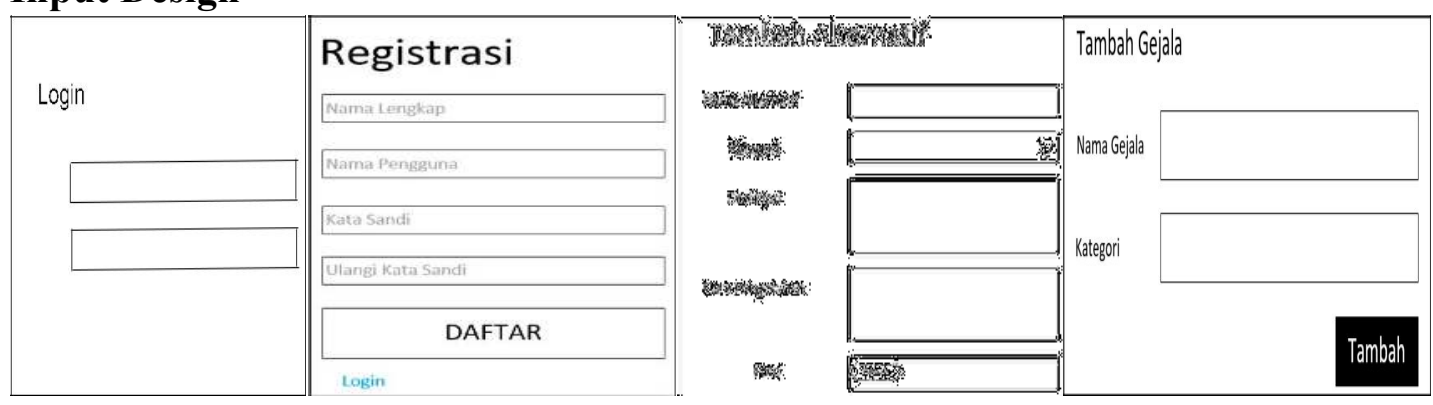

Figure 3. Application Input Design

Figure 3 explains that each user is required to register before logging in to this application and include alternative medicinal plants and symptoms experienced to get an alternative herbal plant that is good for treating cough.

\section{b. Output Design}

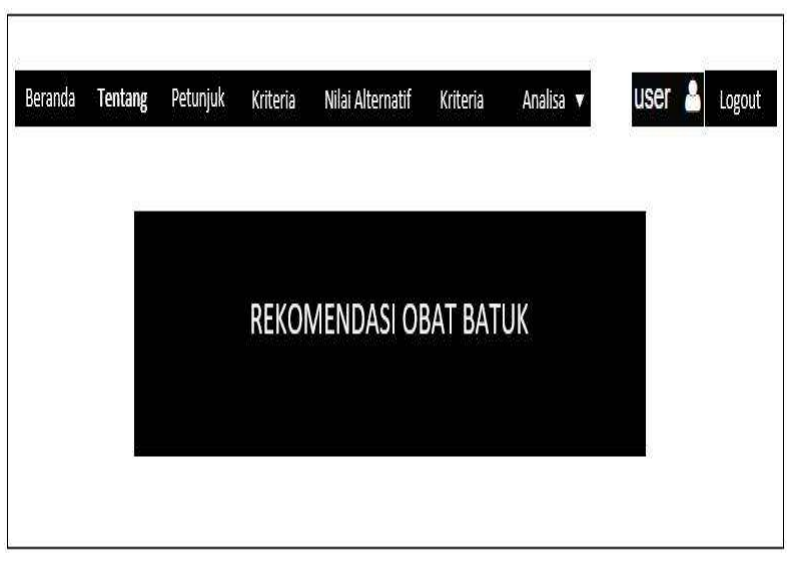

\begin{tabular}{|c|c|}
\hline \multicolumn{2}{|l|}{ Hasil Analisa } \\
\hline \multicolumn{2}{|l|}{ Biodata } \\
\hline Nama & $x x x x x$ \\
\hline Umur & $x x x x x$ \\
\hline Jenis Kelamin & $x x x x x$ \\
\hline \multicolumn{2}{|l|}{ Gejala Yang dipilh: } \\
\hline \multicolumn{2}{|l|}{ 1. $x x x x x$} \\
\hline \multicolumn{2}{|l|}{ 2. $x x x x x$} \\
\hline \multicolumn{2}{|l|}{ 3. $x x x x x$} \\
\hline \multicolumn{2}{|c|}{$\begin{array}{l}\text { Batuk Yang Dideteksi } \\
\text { xxxxx }\end{array}$} \\
\hline \multicolumn{2}{|c|}{ Alternatif Tanaman Obat } \\
\hline $\begin{array}{c}\text { Nama Tanaman } \\
\text { xxxxx }\end{array}$ & $\begin{array}{c}\text { Keterangan } \\
x \mathbf{x x x x}\end{array}$ \\
\hline
\end{tabular}

Figure 4. Application Output Design

Figure 4 is the appearance of the user's main page and the results of the analysis of plant recommendations using the electre method according to the type of cough. On the page above there is a ranking of each alternative plant, the alternative name of the 
value from the calculation results and info in the form of descriptions of plants and methods of processing.

\subsection{Implementation}

a. Electre Implementation

Implementation of the electre algorithm is used in conditions where alternatives that do not match the criteria are eliminated and suitable alternatives can be produced. In other words, electre is used for cases with many alternatives but only a few criteria are involved.

Table 2. Implementation of the Electre Algorithm

\begin{tabular}{|c|c|c|c|c|}
\hline Economic Level & Flavor & Aroma & Effect & Availeble \\
\hline Cheap & Bitter & Quite Stinging & Efektive Enough & Outside Island \\
\hline \multicolumn{5}{|c|}{ Conversion of Environmental Data to Value } \\
\hline Economic Level & Flavor & Aroma & Effect & Availeble \\
\hline 3 & 1 & 2 & 3 & 1 \\
\hline
\end{tabular}

In each case the first thing done is normalization, each attribute is converted into a comparable value that produces A matrix $R$. Then each column of the matrix $R$ is multiplied by the weights determined by the decision maker.

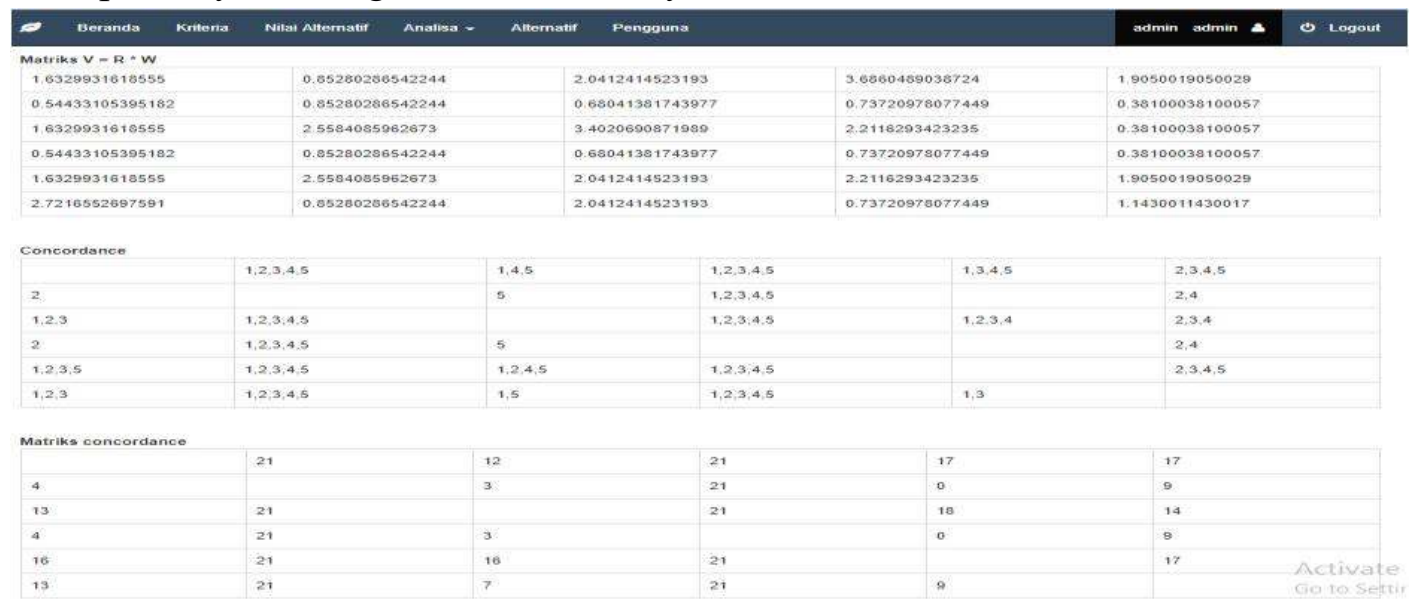

Figure 5. Stage of Implementation of the Electre Algorithm

Figure 5 is a step to determine the value of the concordance matrix elements and the discordance matrix. Then the F matrix is formed as the dominant matrix with a threshold value. At this stage, an E Matrix is formed as aggregate dominance. The E matrix gives a sequence of choices for each alternative.

for $(\$ \mathrm{i}=0 ; \$ \mathrm{i}<\operatorname{count}(\$$ alternatif $) ; \mathrm{i}++)\{$

\$jml_nilai_1_rangking[\$i] $=\$$ jml_nilai_1[\$i];

\$alternatif_rangking $[\$ i]=$ \$alternatif[\$i];

\}

for $(\$ \mathrm{i}=0 ; \$ \mathrm{i}<\operatorname{count}(\$$ alternatif $) ; \mathrm{i}++)\{$ 
Figure 6. Alternative Elimination Listing

b. Program Aplication

In the use of this application the user first creates an account by registering a Full Name Username and Password that will be used.

\section{Beranda Tentang Petunjuk Kriteria Nilai Aternatif Analisa - $\quad$ yeyen user \& 0 Logout}

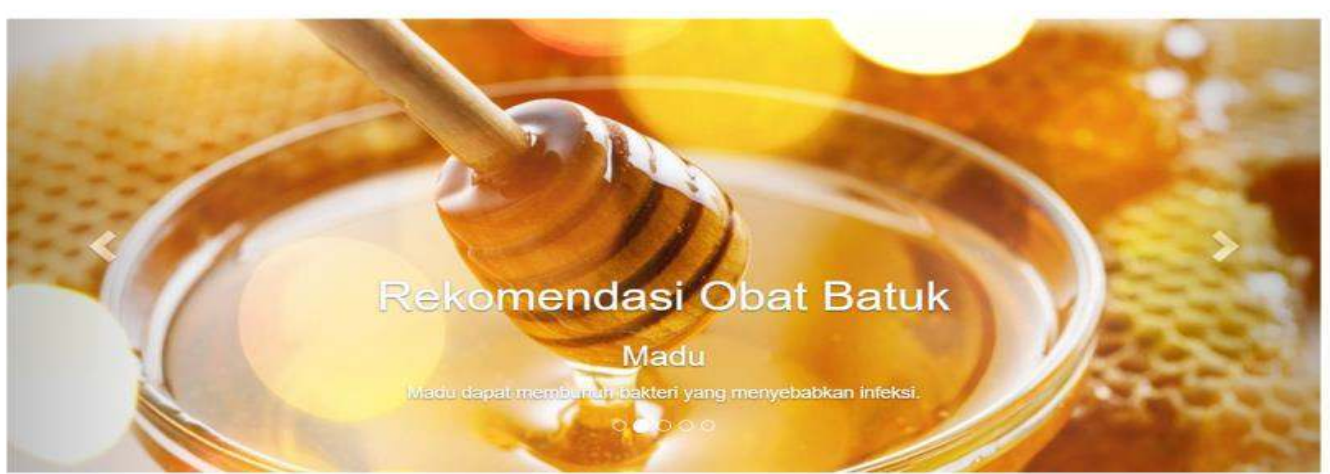

Figure 7. Display of the Main Menu

Figure 7 is the appearance of the admin main page and user. There is a difference between the appearance of admin and user, there are several menus that are not displayed on the user's main page, namely the alternative menu and the user. After that, log in to enter the application.

Login

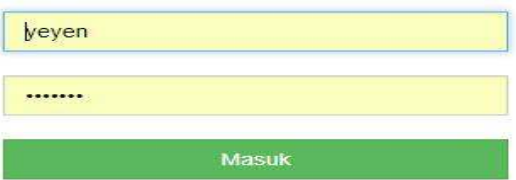


Figure 8. Login Menu

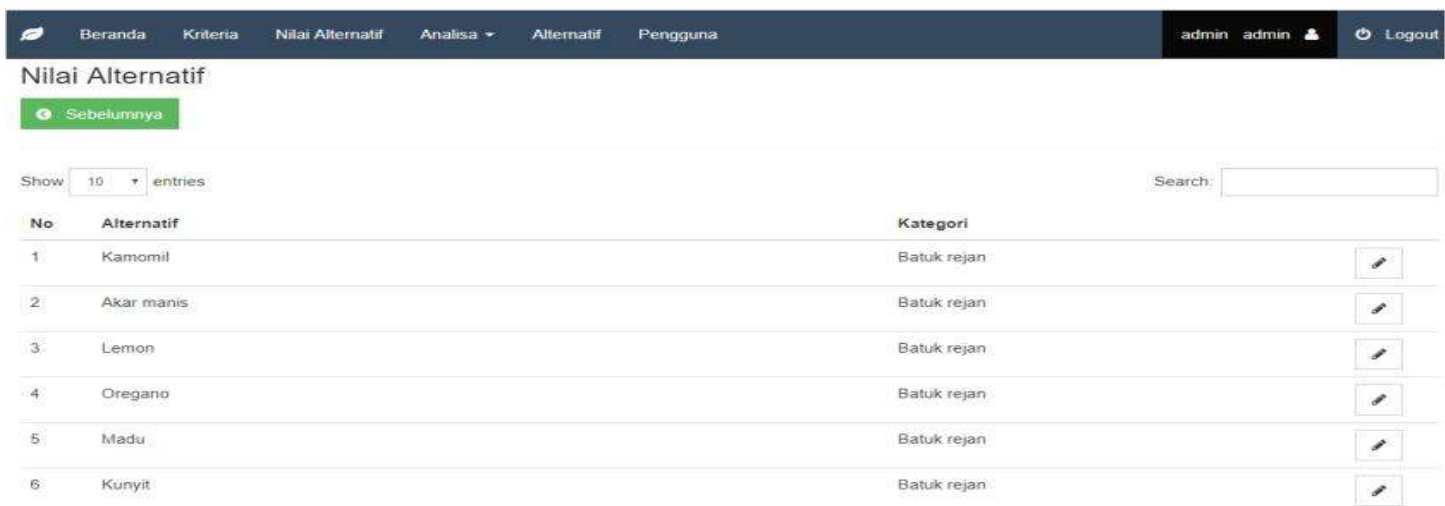

Figure 9. Alternative Value Menu of herbal plants

Figure 9 is an alternative value that displays data from each alternative herbal plant that will be analyzed for use in treating cough.

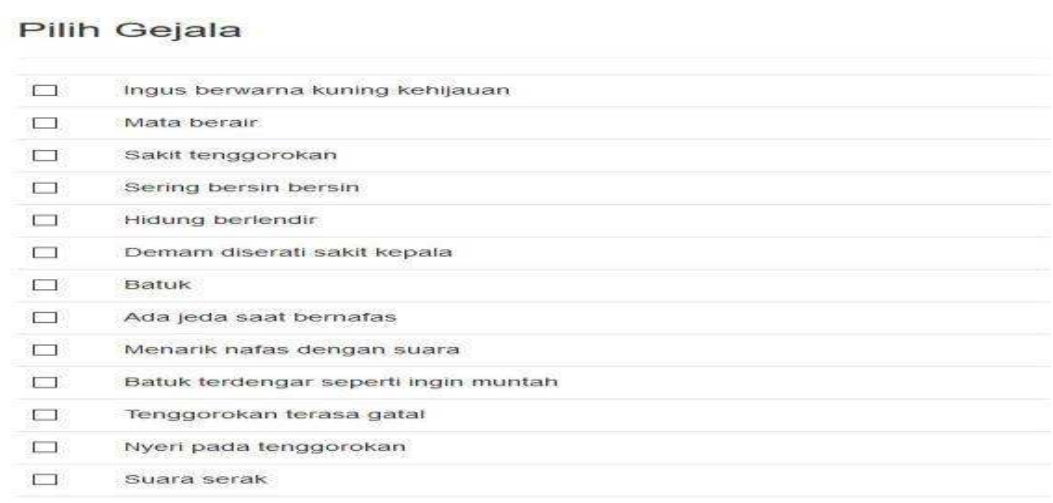

Figure 10. Menu Select Cough Symptoms

In the select symptom menu above displays cough symptoms that will be selected by the user. Then on the symptom menu displays cough symptoms to detect the category of cough before ranking medicinal plants.

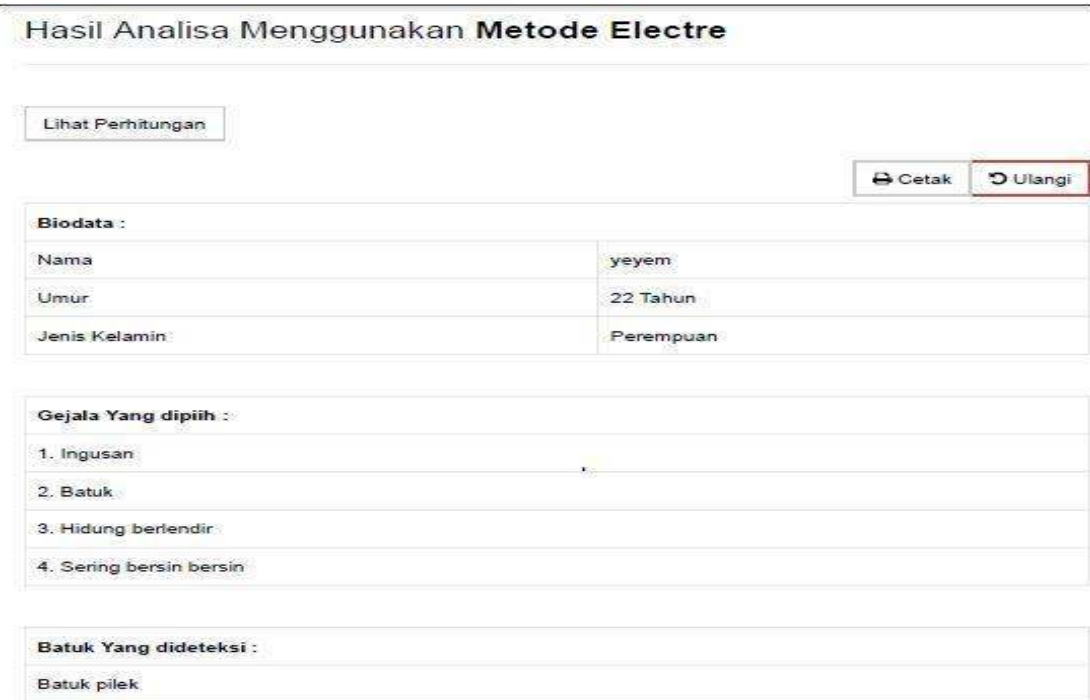


Figure 11. Alternative Analysis Results

Display the results of an alternative analysis. On the results of the analysis, there is rank of each alternative, the value, and description, then the method of processing medicinal plants to cope with a cough that is suffered according to the symptoms chosen by the user.

\section{Conclusion}

From the results of trials to determine herbal cough medicines with trials of several plants from 4 categories of coughing the system can provide recommendations for medicinal plants according to the cough symptoms that have been chosen. The test results of the alpha tests that have been carried out indicate that the application built has met the functional requirements. And beta testing that has been done, namely by testing the calculation of the choice of answer categories from the questionnaire that has been distributed can be concluded that the software built is easy to use and has a pretty good appearance. So that the application of the selection of herbal cough medicines makes it easier for people to choose and recognize medicinal plants that are suitable for coughing suffered and how to circumvent herbal medicines.

\section{References}

[1] Kepmenkes. : Keputusan Menteri Kesehatan RI Nomor HK. 01.07/MENKES/ 187/ 2017 tentang Formularium Obat Tradisional Indonesia. Source: http://dinkes.kedirikab.go.id/konten/uu/96362KMK Nomor HK 0107 MENKES $1872017 \mathrm{ttg}$ Formularium_Ramuan_Obat_Tradisional_Indonesia_pdf . accessed March 1, 2019. (2017)

[2] Sudibyo,S, et al.: Pengobatan Sendiri Sakit Kepala, Demam, Batuk dan Pilek pada Masyarakat di Desa Ciwalen, Kecamatan Warungkondang,Kabupaten Cianjur, Jawa Barat. Majalah Ilmu Kefarmasian,Vol II, No.3 Agustus 2015, 134-144. ISSN: $1693-$ 9883. (2015)

[3] Irianto, K. : Memahami Berbagai Macam Penyakit. Alfabeta CV: Bandung. (2015)

[4] Intan, F, P et al. : Combination of Acupunture Therapy and Turmericliquorice Herbs for Chronic Coughing Case. Journal of Vocational Health Studies p-ISSN: 25807161,e-ISSN: 2580-717x. DOI: 10.20473/jvhs.v1i3.2018.121-125 
[5] Haryo, V, B et al. : Sistem Pendukung Keputusan Penentuan Tanaman Obat Sesuai Jenis Penyakit Menggunakan Metode TOPSIS. Jurnal Informatika Polinema Volume 2, ISSN: 2407- 070X. Politeknik Negeri Malang. (2016)

[6] Ismail, P et a. : Implementasi Analitical Hierarchy Process - TOPSIS dan Borda Pemilihan Tanaman Obat Untuk Penyakit Batuk. JENTIK Prodi Ilmu Komputer FMIPA ULM. (2016)

[7] Utami, M. : Sistem Pendukung Keputusan Pemilihan Obat Batuk menggunakan Metode Weight Produk. Purwekerto: Universitas Muhammadiyah Purwekerto. (2015)

[8] Marlinda, Linda. : Sistem Pendukung Keputusan Pemilihan Tempat Wisata Yogyakarta menggunakan Metode Elimination Et Choix Traduisant La Realita (ELECRE). Jurnal UMJ, TINF-009 p-issn : 2407-1846 e-issn : 2460-8416: Fakultas Teknik Universitas Muhammadiyah Jakarta, November 8, 2016.(2016)

[9] Sutrisno et al. : Sistem Pendukung Keputusan Metode Electre pada Bauran Pemasaran (7P) dalam Memulai Usaha Jasa Center. Jurnal String Vol. 2Desember 2017. p-ISSN: 2527-9661.e-ISSN: 2549-2837. (2017)

[10] Ningsing, P, R et al. : Sistem Pendukung Keputusan (SPK) Pemilihan Tanaman Pangan Berdasarkan Kondisi Tanah Menggunakan Metode ELECTRE dan TOPSIS. Jurnal Pengembangan Teknologi Informasi dan Ilmu Komputer Vol 2, No 8, Agustus 2018, hlm. 2323-2332. e-ISSN: 2546-964X. (2018)

[11] Damanik, Olin Olivia. : Sistem Pendukung Keputusan Pemilihan Siswa Peserta Olimpiade SMA Negeri 1 Lubuk Pakam Deliserdang menerapkan Metode Elimination and Choice Translation Reality (ELECTRE). Pelita Informatika Budi Darma, Volume : IX, Nomor 1, Maret 2015. ISSN : 2301-9425. (2015) 